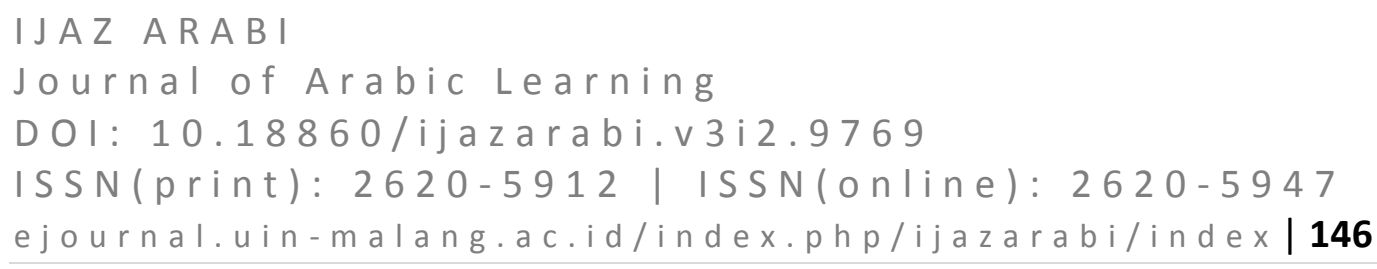

\title{
The Integration Of Qur'an And Linguistic Education Based On Ontology Of Qur'anic Concept In Quranic Arabic Corpus
}

\author{
Nur Ali ${ }^{1}$, Mamluatul Hasanah ${ }^{2}$, Agung Prasetyo ${ }^{3}$ \\ Universitas Islam Negeri Maulana Malik Ibrahim, Malang, Indonesia ${ }^{1,2,3}$

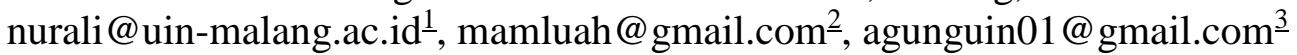

\begin{abstract}
Reseachers of Arabic and Religious Learning program applications are surprised by the phenomenon among students, teachers of Arabic, and Religious Languages in which most of them have never practiced and used The Qur'anic Arabic Corpus (QAC) applications for academic activities. Meanwhile, the program has many benefits and conveniences for students, teachers, and researchers for conducting research and study activities in the field of language and religion and science integration. The number of open-source of IT-based information that can be used for Arabic language learning activities and studies of religious and scientific integration is increasing significantly. This study uses Krippendorf perspective qualitative design in the study of al-Qur'an integration and linguistic education. The research method used is the study of linguistic corpus with annotations, abstractions, and analysis through three stages of corpus exploration, experimentation, and knowledge discovery. Through data analysis, it is found that the Arabic and religious learning model using The Qur'anic Arabic Corpus can improve language creativity and improvisation and improve the process of reciting, memorizing and vocabulary building, making it easier for students to study the integration of Qur'an, language, religion, and science. This paper recommends that Arabic and religious learning activities utilize IT-based learning program applications such as the QAC
\end{abstract}

Keywords: Integration of Qur'an; Linguistic Education; Qur'anic Arabic Corpus

\section{INTRODUCTION}

Application programs for learning the Qur'an and Arabic based on Android allegedly not accustomed to practiced by students and teachers. This is indicated by the phenomenon that most of the students and teachers of Arabic and Religion have never practiced and used the application of The QAC for teaching and learning activities in the classroom (Hasanah, 2016). Meanwhile, this program has many benefits and convenience for them and researchers to carry out research and studies on the integration of language, religion and science (Arum \& Winarti, 2020; Awaludin, 2019; Hizbullah, Rachman, \& Fauziah, 2017; Priyono, 1999; Suaibah \& Rahman, 2020; Sukmana, Gusmita, Durachman, \& Firmansyah, 2015).

Ontology of Qur'anic Concept is stated in The QAC. The selection of the focus of this discussion is seen in five aspects. First, the position of the Qur'an as a source of epistemology in Arabic linguistic studies which is one of the core studies in learning Arabic. Second, the study of the linguistic corpus is still relatively new 
when viewed from its use in the field of learning Arabic. This study is one of the things that inspired the birth of corpus linguistics by Nahwu scholars (Arabic Grammarian) which from the beginning has made the linguistic corpus as a source of data in determining Arabic grammatical rules. Third, the learning activities are now based on information technology and make corpus linguistics as teaching material (Arum \& Winarti, 2020; Priyono, 1999). Besides, the rise of computer science has provided various models of data banks and analyzes (Conrad, 2005). Fourth, institutionally, one of the most significant mandates of the Ministry of Religious Affairs towards the State Islamic University, including UIN Maulana Malik Ibrahim Malang, is to organize activities and the integration of Islam and Science (Ali, 2019). Fifth, based on a previous study conducted by Hasanah (2016), It was found that a quite surprising phenomenon among observers of Arabic both lecturers, teachers, and students of the Department of Arabic Education that 19 out of 20 informants had never known and accessed The QAC, or using it in the process of learning Arabic. Even though the program The QAC issued by Leed University, based on what Farooqui said, is a pioneer in the study of Arabic linguistic corpus based on the Qur'an, which offers many choices that can be utilized in the world of research and learning (Farooqui \& Noordin, 2015). Among the choice that produces plenty of subsequent studies is the Ontology of the Qur'anic Concept which is the focus of this research.

The study of the linguistic corpus that began in 1967 has an expansive area of study. The corpus of linguistics is a branch of discourse analysis that has experienced growth and received phenomenal attention in the past decade. Apart from the weaknesses of the corpus of linguistics that are unable to answer the question "why" in research or other weaknesses which is the existence of the linguistic corpus that cannot represent the whole language data, the selection of corpus linguistic themes in this study is more emphasized on the function of the linguistic corpus itself primarily when being used in the world of learning and multidisciplinary studies (Arum \& Winarti, 2020; Misbahuddin, 2015; Priyono, 1999; Sabil, 2014; Suaibah \& Rahman, 2020). Ontology in this research is ontology in the context of computer science and information sciences. Ontology of Qur'anic Concept is a computational linguistic-based program (Gruber R., 1993) defines ontology as an explicit breakdown of conceptualization, in which the body of knowledge is built based on the conceptualization process. Then (Guardino, 2009) an expert in the field of applied ontology, polished that definition by defining ontology as a logical theory of recording a meaning of formal words.

The scope of studies related to al-Qur'an ontology, computer-based, really takes the attention of researchers. Among them are Arabic WordNet (2014) by (Almaayah, Sawalha, \& Abushariah, 2014), Quran Verse Extraction for Various Concepts (2013), Thematic Classifications by Ta'A, Abdullah, Ali, \& Ahmad (2014), and others; (Hizbullah et al., 2017). As for the study related to linguistic ontology, many linguistic expert figures talk about this concern, such as (Francis, 1993; Halliday, 1991). Utilization of these programs in various fields deserves to 
be applied, and one of the things that this research will do is to utilize them in the study of al-Qur'an integration and linguistics education.

This research is a response to the shortcomings of Arabic enthusiasts and students of the QAC and how to utilize it. Therefore, three questions can be formulated, and they are; (1) What are the choices in the Ontology of Qur'anic Concept program in The Qur'anic Arabic Corpus version 0.4? (2) How are the Characteristics of the QAC?, and (3) How are the formulations of the study of the integration of Qur'an and linguistic education based on Ontology of Qur'anic Concept? These three questions are expected to be able to answer the problems encountered in learning the Arabic language based on the QAC.

The writing is based on two arguments. First, there are 12 categories in the Ontology of Concept menu including; Artifact, Astronomical Body, Event, False Deity, Holy Book, Language, Living Creation, Location, Physical Attribute, Physical Substance, Religion and Weather Phenomena. Secondly. From these 12 categories, it is possible for enthusiasts and Arabic language students to carry out studies on the integration of religion and science easily (Arum \& Winarti, 2020; Awaludin, 2019; Hizbullah et al., 2017; Misbahuddin, 2015; Sukmana et al., 2015).

\section{METHOD}

This study applied a qualitative approach using Krippendorf model with design in the study of al-Qur'an integration and linguistic education researchers are more into the process of achieving design, not yet on the effectiveness of using the product in the study of practical integration in class. The research method used is the method of linguistic corpus studies. The corpus linguistic method has three rules as keywords; annotations, abstractions and famous analyzes are called 3A perspective. In the annotation process, a very large number of corpus are collected, transcribed, standardized, and segmented according to the needs of the researcher. The consistency of the researcher in the annotation process dramatically influences the consistency of the data that can lead to the purpose of his research, because there are many corpora available. Annotations are performed per item of the required data, although at different times annotations can still be performed for different data. The distinction of each of these data is because all data are processed through three stages of the corpus linguistic method, namely corpus exploration, experimentation, and knowledge discovery. The analysis process links between the variables that have been designed up to the question of how to answer the desired research problem. In the context of this research, the results of the cyclical corpus linguistic method are used in the world of language learning.

The primary data in this study is the ontology of Qur'anic concept which is one of the menus in The QAC version 0.4, meanwhile the four data are in the form of choices contained in the program with documentation analysis techniques. The final stage comes to the design of the study of integration between the Qur'an and Linguistic education, the primary data is being the concept of three categories, Holy Book, Language and Religion sourced from The QAC Version 0.4 program. 
In analyzing data related to the menu in the Ontology of the Qur'anic Concept which is one of the menus in The QAC. The researcher uses the analysis of qualitative content which was adapted from (Krippendorf, 1989) with the procedure namely; (1) thorough reading of the choice contained in The QAC Program (raw observation), (2) conducting units which include the determination of units, separating data according to their limits and identification for subsequent analysis, (3 ) determine the data to be analyzed (sampling), (4) take notes on the data that has been set for analysis (recording), (5) reduce the data by means of researchers sorting and selecting any relevant data to answer the formulation of the problems raised in the study this, (6) making finding that has been identified, (7) conducting validations adapted from Lincoln and Guba, namely continuous observation, utilizing sources outside the analyzed data (triangulation ) and discussion with experts (peer debriefing) (Bungin, 2007; Moleong, 2004).

\section{RESULTS AND DISCUSSION}

\section{The Choices in The Ontology of Concept in The Quranic Arabic Corpus}

Qur'anic ontology has been the ontological focus that studied in the menu of ontological concept in the QAC. The concept contained in this menu aims to explore the Quranic ontology using common knowledge representation in defining key concepts in the Qur'an. Its also used to show the relationship between each concept using predictive logic. In this case, researcher will briefly explain the meaning of knowledge representation and predictive logic which is used as a foundation by the menu maker in designing qur'anic ontological menu, before further explain about the use of ontological concept menu for integration studies of qur'an and educational linguistic.

The knowledge representation meant the basic concept in ontology based on Qur'an and Hadith. The main source of the QAC menu was Tafsir Ibn Katsir. The name of entities contained in the verses, like place name, peoples' name, or others are connected each other to discover the new concepts. In this menu, there are around 300 concepts, after explained each other relationship, it was found 350 relations.

The predictive logic is an extension of prepositional logic, so that the concept of objects and relationships between subjects can be expressed in the language of logic. A predicate is a function of one or more arguments whose results are true or false. In the language of predicate logic, the second and third sentences are the embodiments of abstract sentences, with the motivation that objects and relations between objects can be expressed in a logic language, logic rules are made called predicate logic. For further reading of this logic can be read in logical books.

Ontology of concept present a list of the main concept in the Qur'an, and than defines the semantic relationship between one concept to another. One of the important relations presented in this menu is membership relations. Such us, the concept of an "astronomical body" consisting of the sun, the earth and the moon. Another example in describing the semantic relations, is when its mentioned that 


\section{IJAZ ARABI}

Journal of Arabic Learning

DOI: $10.18860 / \mathrm{ijazarabi.v3i2.9769}$

ISSN(print): 2620-5912 | ISSN(onIine): 2620-5947

ejournal.uin-malang.ac.id/index.php/ijazarabi/index /

"devil is jin" in the ontology represent the knowledge contained in the Qur'an that individuals referred to as Syaitan are included in set of living creatures called Jin.

Another important thing that needs to be understood in this menu is the term Pronoun Resolution. The procedure for interpreting expressions, in which many pronouns or phrases occur, was a very crucial system in linguistic computing. For example, if there are word entities that enter the system, the system must be able to be made to identify the meaning of the word that appears. In the Qur'anic Arabic Corpus, the word morphology segment is linked to the concept of ontology to facilitate the understanding of pronouns. For the example in Surat Al-Qadr in the first verse.

In understanding this verse, the pronoun "hu" is not explicitly refers and mention the word Al-Qur'an. Likewise the pronoun " $\mathrm{Na}$ " is also not explicitly stated and refers to Allah. In the Ibn Katsir, pronoun "hu" is refers to Al-Qur'an, and pronoun "na" refers to Allah. By this system, claimed that pronoun "Hu" is refers to the concept of "Qur'an" and "Na" is refers to the concept of "Allah". In addition to the problem of understanding pronouns, another important aspect to be informed about this menu is related to mubham word or the word that has uncertain meaning in the Qur'an, the way of understanding. It will be related to the concept of ontology. For example when interpreting " aيلة القدر" after tracing it in the Ibn Katsir, it was found that the Lailat Al-Qadr is one of the nights in the holy month of Ramadlan. So that, the meaning of "ليلة القدر" In this system are linked with the concept of Ramadhan. It will appeared like below picture:

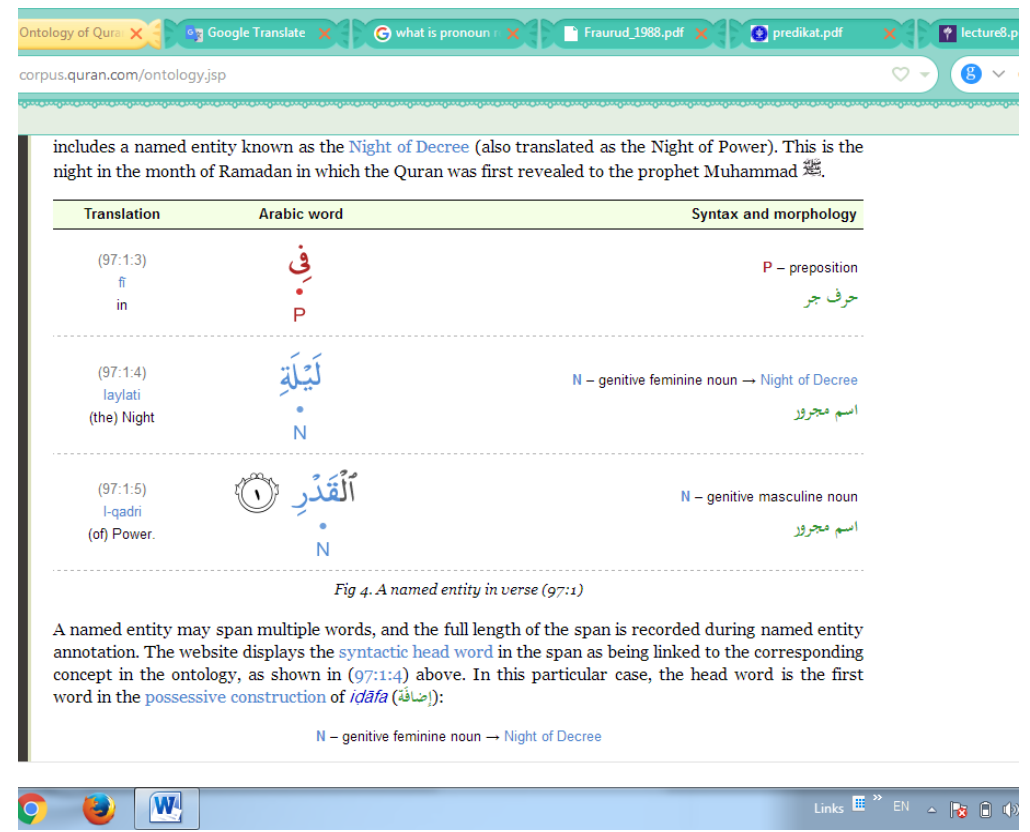




\section{Ontology of Concept Menu and the Characteristics}

The main menu of this Ontology of Concept are divided into two which are Concept Map and Topic Index. The descriptions of each concept and the characteristics are below:

\section{Concept Map}

This menu will present several other menus to discuss Qur'anic Ontology. The concepts that emerge will be classified in various categories and sub categories. This categorization appears in the sub categories menu. After that, the relationship between each category will be raised with the main concept, namely God (Allah). And the relationship of each category is visualized in the form of concept map that is presented in the visual concept map menu. The findings of the concept relationship that is built based on this predictive logic will create new knowledge as a form of relationship between the concepts. This knowledge is presented in the knowledge base menu.

\section{Concept}

The concept is the name of root entity in the Qur'anic Ontology. All other concepts and subcategories in the ontological hierarchy are based on this basic concepts.

\section{Sub Categories.}

In this menu, will be visualized 12 sub categories concept those are:

\section{1) Artifact}

Artifact is a category that refers to human artificial construction mentioned in the Qur'an. This category has two sub categories which is place of worship and weaponry. There are ten concept related to this category such us: Ark of the Covenant (دهفينة), (درابوت العهيم), Boat), Ink (حراهب), Key (مفتاح), Ladder

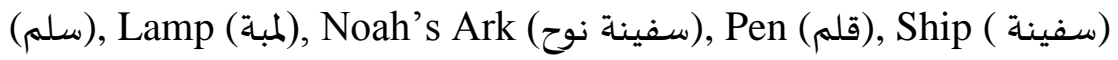

\section{2) Astronomical Body}

The astronomical body is a category refers to astronomical object mentioned in Qur'an. This concept has six categories; Constellation (ألبروج), Earth (أرض), Moon (القمر), Sirius (الثعري), Star (نجم, Sun (الثمس).

3) Event

Event is a category that refers to certain or particular event that is bound by time mentioned in Qur'an. This category has four sub categories: Afterlife Event, Calender Event, Historic Event, Physical Event

4) False Deity

False deity related to the worship of false gods mentioned in the Qur'an. This concept has one sub category that is Idol (الاصنام) and other nine concepts

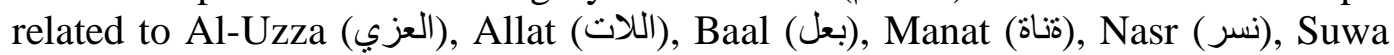
(سو اع), Wadd (واد), Yaghuth (يغوث), Yauq (بعوق)

\section{5) Holy Book}




\section{IJAZ ARABI}

Journal of Arabic Learning

DOI: $10.18860 / \mathrm{ijazarabi.v3i2.9769}$

ISSN(print): 2620-5912 | ISSN(onIine): 2620-5947

ejournal.uin-malang.ac.id/index.php/ijazarabi/index/

Holy Book is a category related to holy book and other religious texts mentioned in the Qur'an. This category has four sub categories: Injeel (الانجيل), Quran (القران), Torah ('آنوان Zabur (زبور)

6) Language

Language is a category that refers to the language mentioned in the Qur'an. This category has sub category which is Arabic.

7) Living Creation

Living Creation is refers to living creature of Allah mentioned in Qur'an. This category has to sub categories: Organic Object and Sentien Creation

8) Location

Location is a category that refers to a place and another location mentioned in the Qur'an. This category has two sub category: Afterlive Location and Geograpichal Location.

9) Phycical Attribute

Physical attribute is a category that refers to physical attribute. This category has one category which is color (لون)

10) Physical Substance

This is a category refers to physical substance mentioned in the Qur'an. This category as two subcategories and eight related concepts. The subcategories are: metal and mineral. The related concepts are: Clay (صلصال), Coral (مرجان), Dust (نراب), Glass (زجاج), Oil (زيت), Pearl (لؤلؤ), Slik (حرير), Soil (ثرى)

11) Religion

Religion is a category that refers to the big religions, or other encient beliefs mentioned in the Qur'an. This category has 5 related concepts: Christianity (النصارى), Islam (الاسلام), Judaism (اليهود), Magians (المجوس), Sabian (الصابئين)

12) Weather Phenomena

Weather Phenomena is a category that refers to several kinds of phenomena mentioned in the Qur'an. This category has 4 related concepts related to the weather: Cloud (سحاب), Lightning (برق), Rain (مطر), Thunder (رعد))

\section{Topic Index}

The topic index in the menu of Arabic Qur'anic Corpus provide the information concept from the Qur'anic Ontology that arranged in alphabetical order. The index list in A alphabet are consist of 25 concepts: Aad (عاد), Abel (هابيل), Abu Lahab (أبو لهب), Adam (آحمد), Ahmad (الحمد), Al-Ahqaf (الحمقاف), Al- Jahiliyah

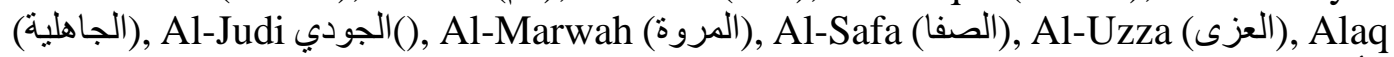

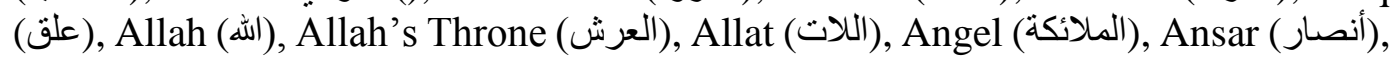
Ant (نمل), Ape (نرد), Arabic (العربية), Ark of the covernant (نابوت العهد), Arrow (سرد)),

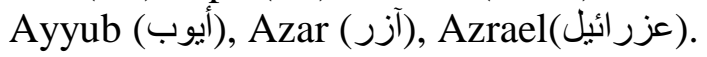

B alphabet is consist of 13 concepts: Baal (بعل), Babylon (بابل), Badr (بدر)),

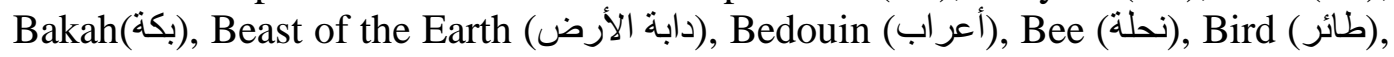

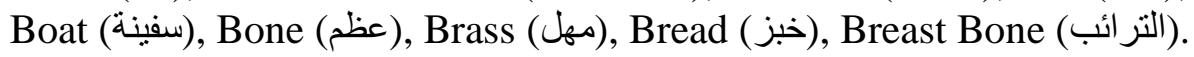




\section{IJAZ ARAB I}

Journal of Arabic Learning

DOI: $10.18860 / \mathrm{ijazarabi.v3i2.9769}$

ISSN(print): $2620-5912$ | ISSN(online): $2620-5947$

ejournal.uin-malang.ac.id/index.php/ijazarabi/index/ $\mathbf{1 5 3}$

C alphabet is consist of 22 concepts: Cain (جمل), (جل), Carrion (الميئة), Children of Adam (بني آدم), Children of Israel (بني إسرائيل), Christianity (النصارى), Church (كنيسة), Clay (سلصال), Cloud (سحاب), Coat of Mail (سابغات), Coin (دراهم), Color (لون), Companions of the Cave (أصحاب الكهن),Companions of the Elephant (أصحاب الفيل),Companions of the Pit (أصحاب الأخدود),Companions of the Rass (أصحاب الرس),Companions of the Wood (أصحاب الأيكة), (البرد), Constellation (البروج), Coral (مرجان), Cow (بقرة), Cucumber (فناء)

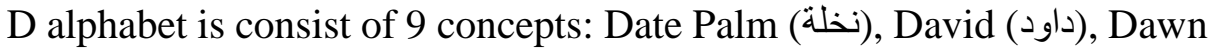
(فجر), Day of Resurrection (يوم القيامة), Desert (صحراء), Dhul Kifl (ذو الكرن), Dhul

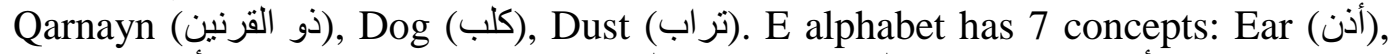

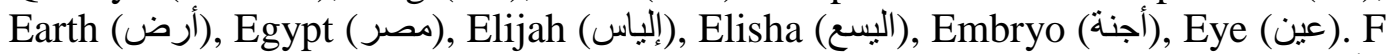

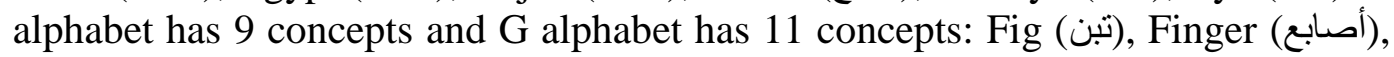

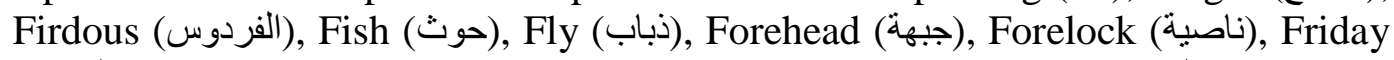

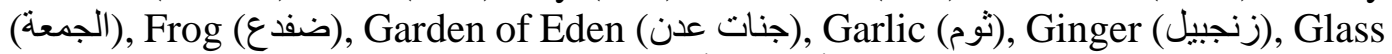

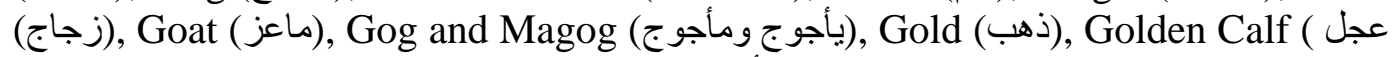

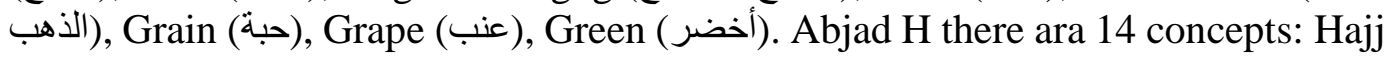

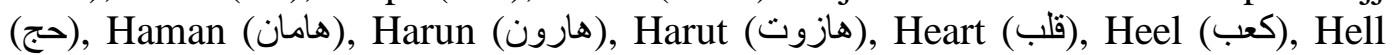

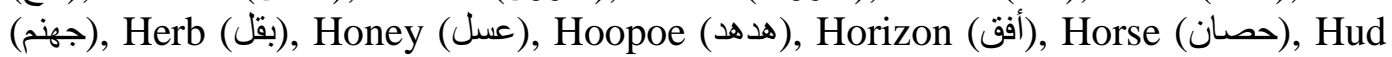
(هود), Hunayn (هنين).

I alphabet has 14 concepts: Iblis (إبليس), Ibrahim (إبر اهيم), Idol (الألير)),

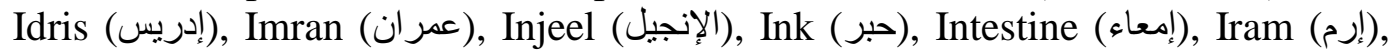

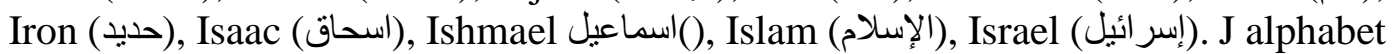

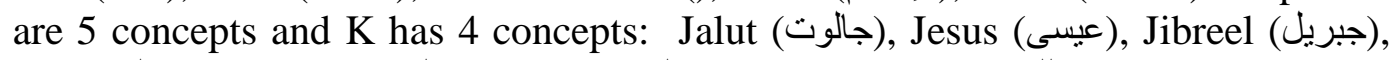
Jinn الجن()( اليهود), Judaism (مفتاح), Kaaba (الكعبة), King (ملك), Knife (سكينة),

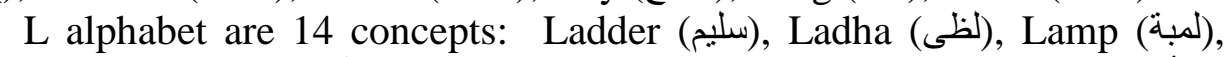

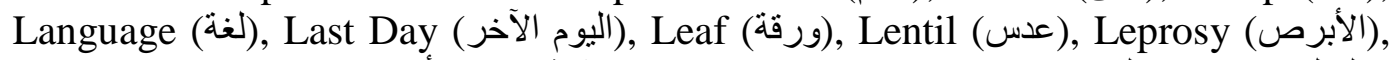

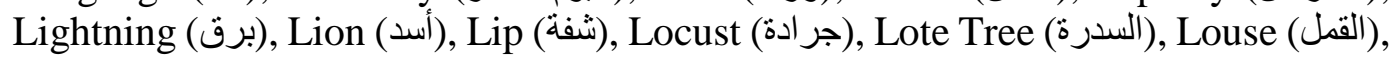

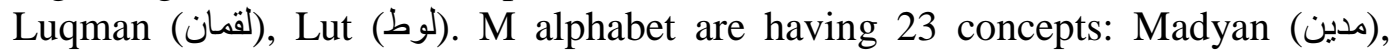
Magians (المجوس), Makkah (مكة)), Malik (مالكاة), (ماروت), Manat (منات), Maryam (مريم), Masjid al-Aqsa (المسجد الأقصى), Masjid al-haram (المسجد الحرام), Meat (لحور) (لحم), Medinah (المدينة المنورة) Messiah (المسيح)), Mikaeel (ميكائيل), Milk (لبن), Monastery

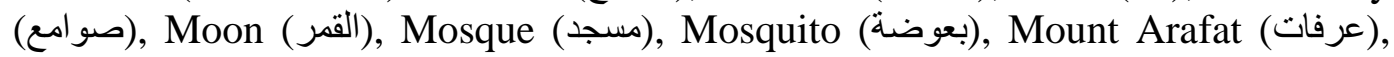

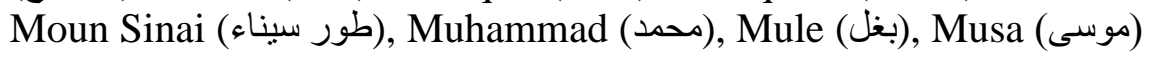

$\mathrm{N}$ alphabet has 4 concepts, $\mathrm{O}$ are 3 concepts and $\mathrm{P}$ are 8 concepts: Nasr

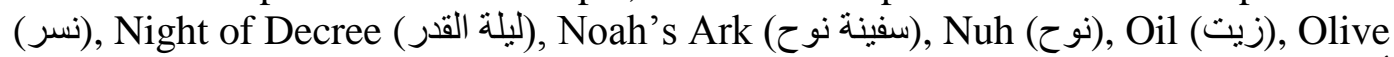

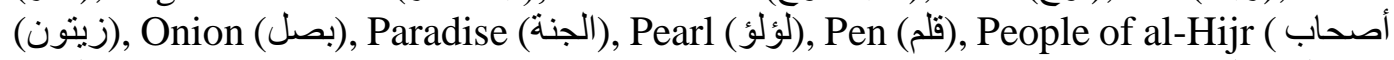

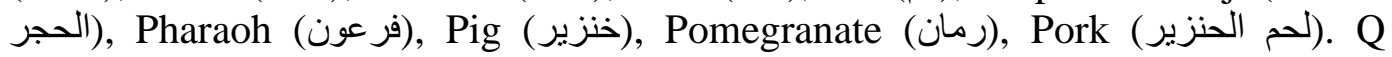
alphabet has 5 concepts and R are 4 concepts: Qarun (قنان) (قبلة), Qنارون), Quail

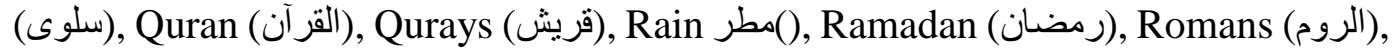
Ruby (ياقوت) .

S alphabet has 25 concepts: Sabbath (السبت), Sabians (الصابئين), Salih (ساح), Salsabil (سلسبيل), Salt (السامري), Saquiri (سلح), Satan (الثقان), Sheba (سبأ), Sheep (غنم) (شعينة), Ship (سجيب), Sijeen (سجين), Silk (حرير), Silver 
Journal of Arabic Learning

DOI: $10.18860 / \mathrm{ijazarabi.v3i2.9769}$

ISSN(print): $2620-5912$ | ISSN(onIine): $2620-5947$

ejournal.uin-malang.ac.id/index.php/ijazarabi/index/ $\mathbf{1 5 4}$

(فضة), Sirius (الثعري), Snake (حبة), Snout (حرطوم), Soil (تروى), Solomon Spider (سليمان), Star (سواع), (الثمسي), Sinagogue (صلو اتون).

T alphabet has 7 concepts, U has 3 and W has 4 concepts: Talu (طوان) (لعرد),

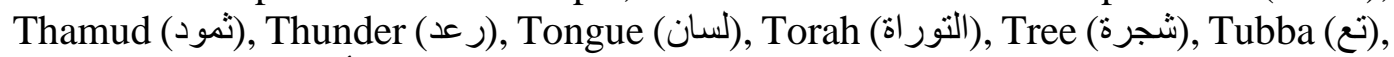

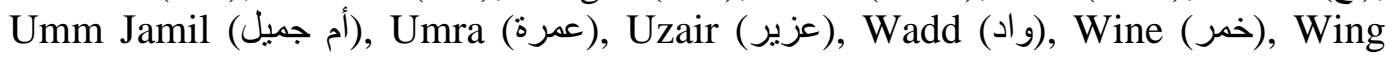
(ناح), Wofl (نئب). Y alphabet has 7 concepts and Z has 4 concepts: Yaghuth (يغر) (ينون), Yahya (يحيى), Yaqub (يحقوب), Yathrib (يثرب), Yauq (يعوق), Yunus (يونس), Yusuf

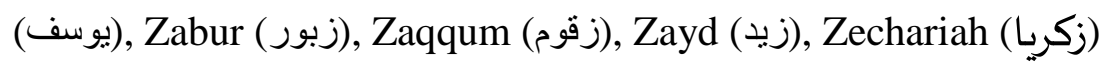

The above menus have been explained globally and those menus that will be utilized by researcher as a main source in designing the Qur'anic and linguistic educational studies that have become the $2^{\text {nd }}$ research question of this research.

\section{a. The Formulations of The Study of the Integration of Qur'an and Linguistic Education Based on Ontology of Qur'anic Concept}

The most frequently asked question when discussing this topic is what is the speciality of the Qur'an when it becomes a source of data for ontology research. If this is related to corpus research, it can be said tha Qur'an is an extraordinary source of corpus data because of some reasons (Sabil, 2014; Sharaf \& Atwell, 2012). firstly, Qur'an is a data that is guaranteed of its existence and validity because it is maintained by the Muslim community from centuries to centuries. Second, to achieve this data does not require large costs or even free. Third, understanding of the Koran is facilitated with a variety of references that are available sufficiently and can be reached from century to century, so that it will be easy to find the concept of ontology and relations between concepts easily and guaranteed validity.

In the context of this study, researchers will utilize the linguistic corpus for the integration study design. The Arabic Qur'anic Corpus, provides very adequate data to help find integration studies. This research focuses on the study of al-Qur'an integration and linguistic education. Therefore the right data is taken only data related to the study, namely the ontology of concept menu with sub-categories Language, Holy Qur' an and Religion.

The integration design procedure follows the following steps: 1) Tracing the concepts, categories, sub categories of Language, Holy Qur'an and Religion. 2) To make it easier to explore the concept of researchers also use the Topic Index menu. 3) Tracing the relation of ontology concepts using predictive logic so that each concept is found subclasses and instances. 4) Each concept found will be searched for verses and their relationship with other verses that are in one group of concepts (munasabah al-ayat). 5) From this verse, the Qur'anic ontology concepts and educational linguistics will be drawn. The above procedure was adapted from several approaches in the study of computer-based al_quran ontology from Arabic WordNet to arrive at the Qur'an ontology in the following chart (Almaayah et al., 2014). 


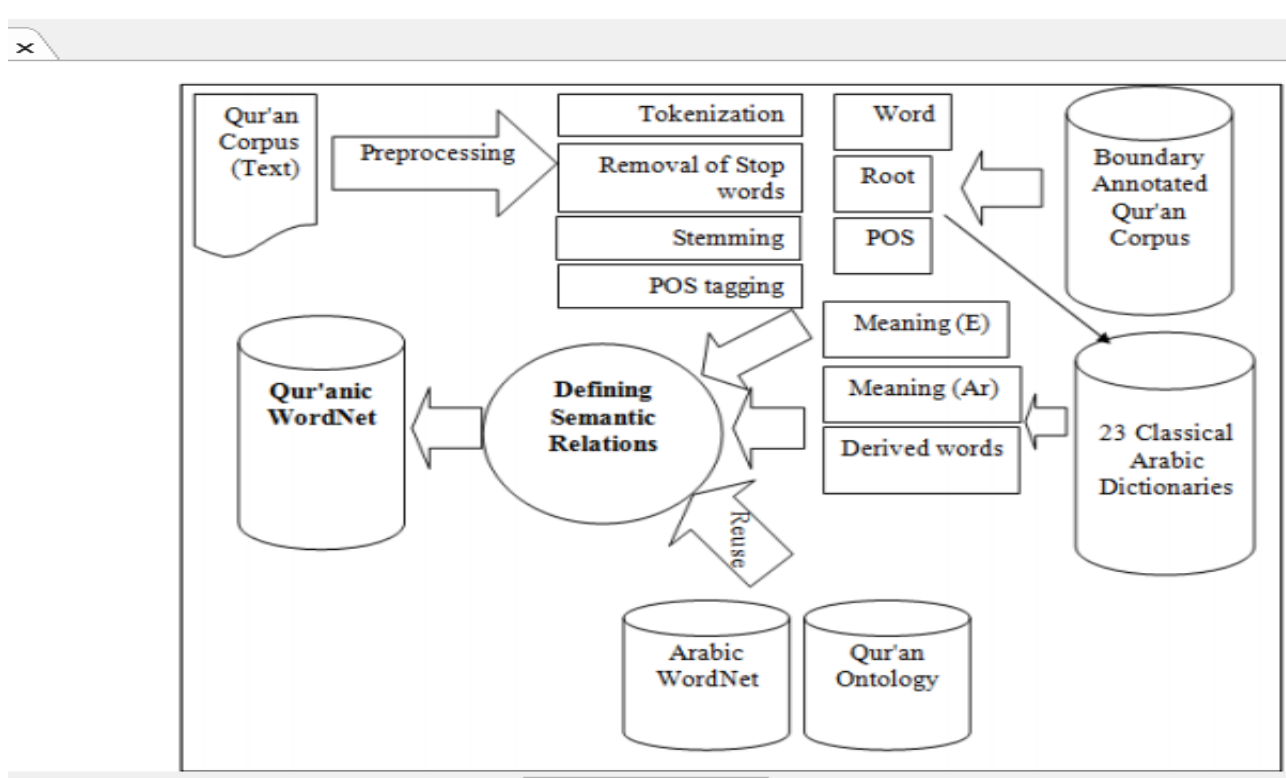

Al-Qur'an is a holy text that contains about 79,000 thousand words scattered in 114 letters (chapters). The techniques used in retrieving information from the Qur'an can be grouped into two, first, semantic and keyword based. Semantic-based technique is a concept-based search tool that is taken based on meaning, while keyword-based is taken based on letters that correspond to words. In general, the system retrieves information usually using keywords. The existing semantic search techniques of the Qur'an are based on ontology, 2) based on set of synonyms, 3) cross-language based (Hizbullah et al., 2017; Priyono, 1999; Sharaf \& Atwell, 2012). The ontology-based approach is a concept search in accordance with the findings of the user, while the synonym set approach is an approach that searches for synonyms using WordNet, then traces the verses that match the word synonyms found. The cross-language based approach is the translation-based approach.

Second, finding the integration design of the Qur'an and Linguistic education, researchers usually depart from the determination of concepts that will be used as a basis. Determination of the concept starts with studies of linguistic education. Before making the determination, the researcher briefly explained how the Qur'anic relation to language creativity since its emergence until now. From a historical perspective, the Qur'an is a miracle that Allah bestowed on the Prophet Muhammad. The Qur'an is a linguistic skill that has tremendous implications for the use of human language creativity. Al-Qur'an which was born in the literary community, where at that time al-quran as a language that is unmatched by its miracles. With the presence of al-Qur'an, a lot of creativity was born by the Muslim 


\section{IJAZ ARABI}

Journal of Arabic Learning

DOI: $10.18860 / \mathrm{ijazarabi.v3i2.9769}$

ISSN(print): 2620-5912 | ISSN(onIine): 2620-5947

ejournal.uin-malang.ac.id/index.php/ijazarabi/index

community. The following diagram illustrates the implications of reciting verses of the Qur'an to human creativity as explained by al-Dhahri in (Zaid, 2011).

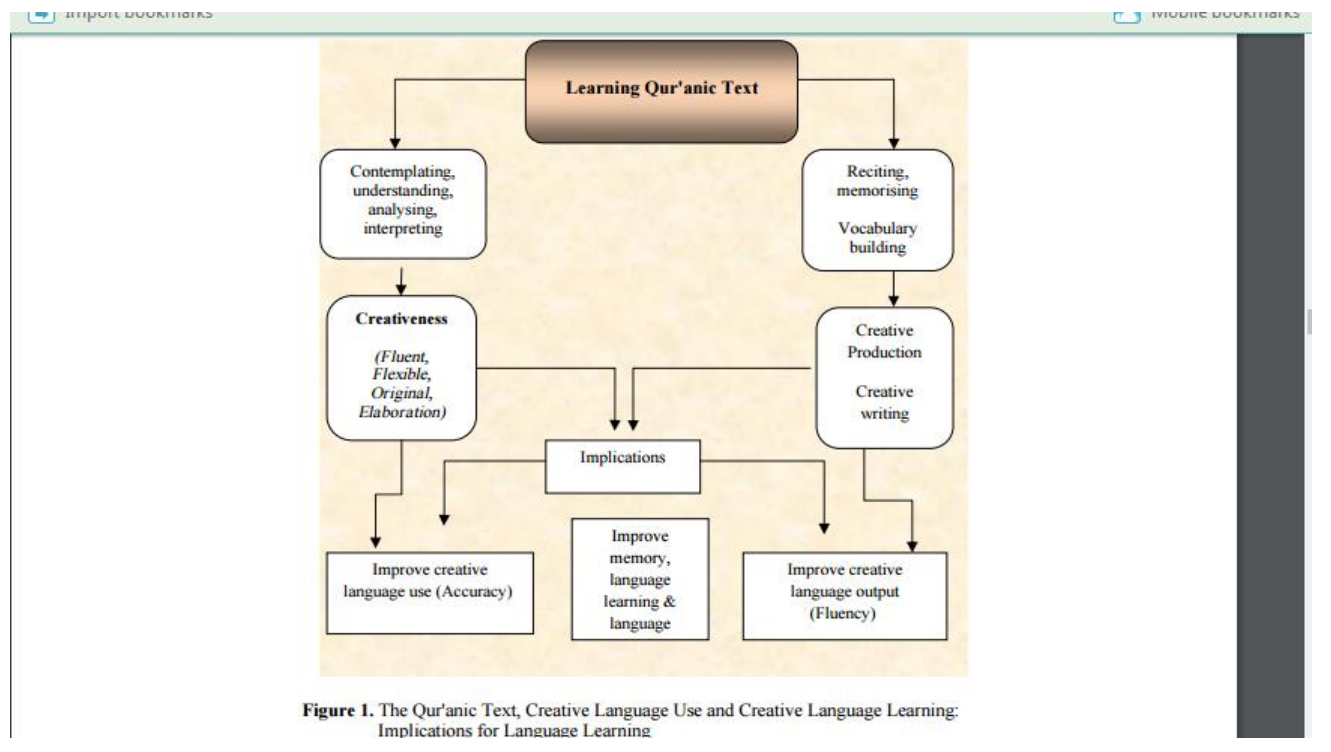

Al-Dhahri's findings also became the initial step of the researcher in studying terms in linguistic education namely how learning the Koran with existing patterns can build language creativity so that people reading the text of the Koran always have implications for four processes: contemplating, understanding, analyzing, and interpreting. These four processes also give birth to four creativity, namely fluency, flexible, original, and elaboration. And these four things that later led to the improvisation of creativity in the use of language which in the evaluation language emphasized on the aspect of accuracy.

The reading of the Qur'an also encourages the reader in the process of reciting, memorizing and vocabulary building. This has led to the creativity of language production both oral and written. And this is what then motivates the emergence of improvised linguistic output which is usually in the evaluation language referred to as the fluency aspect of language. From this process was born ontology the relationship between learning the Qur'an with language learning, namely The Qur'anic text, creative language use and creative language learning, improve, memory, and can also draw closer to Allah and increase worship (Aqma Norzaman, Shaari, Azlin Abd Rahman, Utaberta, \& Jaafar, 2017; Awaludin, 2019).

\section{CONCLUSION}

The menu contained in the Ontology of Concept is the concept map and topix index. The menu is to describe and explore the Qur'an's ontology by using knowledge representations to define key concepts in the Qur'an, and to show the relationships between concepts using predictive logic. The integration design 


\section{IJAZ ARAB I}

Journal of Arabic Learning

DOI: $10.18860 / \mathrm{ijazarabi.v3i2.9769}$

ISSN(print): 2620-5912 | ISSN(onIine): 2620-5947

ejournal.uin-malang.ac.id/index.php/ijazarabi/index/

process in tracing concepts, categories, sub categories from Language, Holy Qur'an and religion using 4 procedures. First, to facilitate the search for concepts and use the Topic Index menu. Second, explore the relation of ontology concepts using predictive logic so that each concept is found subclasses and instances. Third, each of the concepts found will be searched for verses and their relationship with other verses that are in one group of concepts (munasabah al-ayat). Fourth, from this verse we can draw concepts from the Qur'an's ontology and linguistic education.

From this process it was found that learning the Qor'an with existing patterns so far can build language creativity and give birth to improvised creativity in the use of language. From this process can drive the process of reciting, memorizing and vocabulary building so as to bring out the creativity of language production both oral and written and can increase understanding of the content of the Qur'an and the development of scientific integration studies. This research is still a basic stage of design that has not been tested. So for future researchers to examine and review this design to become a more established design

\section{REFERENCES}

Ali, N. (2019). Integrative curriculum of religion and science at special pesantren for univerity students. ULUL ALBAB Jurnal Studi Islam, 20(1), 95-122. https://doi.org/10.18860/ua.v20i1.6353

Almaayah, M., Sawalha, M., \& Abushariah, M. A. M. (2014). A Proposed Model for Quranic Arabic WordNet. Proceedings of the 2nd Workshop on Language Resources and Evaluation for Religious Texts, 9-13. Retrieved from http://eprints.whiterose.ac.uk/81550/

Aqma Norzaman, N. Z., Shaari, N., Azlin Abd Rahman, K. A., Utaberta, N., \& Jaafar, J. M. (2017). Integrating Asma ul Husna values for design excellence. Pertanika Journal of Social Sciences and Humanities, 25(August), 33-40.

Arum, E. R., \& Winarti, W. (2020). Penggunaan linguistik korpus dalam mempersiapkan bahan ajar english for specific purpose di bidang radiologi. Jurnal Teras Kesehatan, 2(2), 58-69. https://doi.org/10.38215/jutek.v2i2.39

Awaludin, A. (2019). Resource based learning for teaching arabic. Ijaz Arabi Journal of Arabic Learning, 2(1), 77-91. https://doi.org/10.18860/ ijazarabi.v2i1.6612

Bungin, B. (2007). Metodologi penelitian kualitatif: Aktualisasi metodologis ke arah ragam varian kontemporer. Jakarta: PT Raja Grafindo Persada.

Conrad, S. (2005). Corpus Linguistics and L2 Teaching dalam E. Hinkel. Handbook of Reseach in second languange teaching and Learning. NJ: Lawrence Erlbaum Associattes.

Farooqui, N. K., \& Noordin, M. F. (2015). Knowledge exploration: Selected works on Quran ontology development. Journal of Theoretical and Applied Information Technology, 72(3), 385-393. 
IJAZ ARAB I

Journal of Arabic Learning

DOI: $10.18860 / \mathrm{ijazarabi.v3i2.9769}$

ISSN(print): $2620-5912$ | ISSN(online): $2620-5947$

ejournal.uin-malang.ac.id/index.php/ijazarabi/index | $\mathbf{1 5 8}$

Francis, G. (1993). A Corpus-driven approach to grammar-principles, methods and examples. In Baker, M., Frarcis, G, and Tognini-Bonelli, E. (Eds.).Text and technology: In honor of John Sinclair. Amsterdam/Philadelphia: John Benjamins Publishing Company.

Gruber R., T. (1993). Toward Principles for the Design of Ontologies Used for Knowledge Sharing. International Journal of Human-Computer Studies, 43(5-6), 907-928.

Guardino, N. at. al. (2009). dalam S. Staab and R. Studer (eds.), Handbook on Ontologies, International Handbooks 1 on Information Systems. https://doi.org/10.1007/978-3-540-92673-3,

Halliday, M. A. K. (1991). Corpus studies and probabilistic grammar. In In Aijmer, K. and Altenberg, B. (Eds.). English corpus linguistics: Studies in honour of jan Svartvik. New York: Longman.

Hizbullah, N., Rachman, F., \& Fauziah, F. (2017). Penyusunan model korpus AlQur'an digital. JURNAL Al-AZHAR INDONESIA SERI HUMANIORA, 3(3), 215. https://doi.org/10.36722/sh.v3i3.209

Krippendorf, K. (1989). content analysis. In The International Encyclopedia of Political Communication (Vol. 1, pp. 403-407). Retrieved from http://repository.upenn.edu/asc_papers

Misbahuddin, I. (2015). Epistemologi Al-Quran dalam membangun sains Islam. Teologia, 26(1), 3-15.

Moleong, L. J. (2004). Metodologi Penelitian Kualitatif. Bandung: Rosdakarya.

Priyono. (1999). Prospek penggunaan korpus untuk studi kebahasaan dan proses pembelajaran bahasa kedua. Jurnal Ilmu Pendidikan Universitas Negeri Malang, 6(2), 75-88. https://doi.org/10.17977/jip.v6i2.703

Sabil, J. (2014). Masalah ontologi dalam kajian keislaman. Jurnal Ilmiah Islam Futura, 13(2), 142-159. https://doi.org/10.22373/jiif.v13i2.67

Sharaf, A. B. M., \& Atwell, E. S. (2012). QurAna: Corpus of the Quran annotated with Pronominal Anaphora. Proceedings of the 8th International Conference on Language Resources and Evaluation, LREC 2012, (May 2012), 130-137.

Suaibah, L., \& Rahman, T. (2020). Smart tree learning media - We can be based on android For arabic subjects. Ijaz Arabi Journal of Arabic Learning, 3(1), 76-93. https://doi.org/10.18860/ijazarabi.v3i1.8215

Sukmana, H. T., Gusmita, R. H., Durachman, Y., \& Firmansyah, A. F. (2015). Development of semantic Web of Indonesian Qur 'an.

Ta'A, A., Abdullah, M. S., Ali, A. B. M., \& Ahmad, M. (2014). Themes-based classification for Al-Quran knowledge ontology. International Conference on ICT Convergence, (July 2018), 89-94. https://doi.org/10.1109/ICTC.2014.6983090

Zaid, M. A. (2011). Language acquisition, linguistic creativity and achievement: insights from the Qur'an. Kemanusiaan, 18(2), 75-100. 